\title{
Thilachium madagascariense (Capparaceae), a new species from eastern Madagascar with a key to the species of the genus
}

\section{Silvio Fici $^{1}$ (D)}

Summary. Thilachium madagascariense Fici, a small tree characterised by 1-foliolate leaves with articulate petioles, leaf blades elliptic or narrowly obovate with base attenuate and apex acuminate, flowers in groups of $2-3$ at the top of lateral twigs and a high number of stamens, is described and illustrated from forest habitats of eastern Madagascar. The new species is similar to $T$. laurifolium Baker, a species endemic to central and eastern Madagascar, differing in the longer leaves with acuminate apex, flowers conferted at the top of lateral twigs, shorter pedicels, higher number of stamens and shorter gynophore. Its affinities are discussed and an updated key is provided for all the species of the genus Thilachium.

Key Words. endemism, historical collections, 1-foliolate leaves, taxonomy.

\section{Introduction}

The genus Thilachium Lour. (Capparaceae Juss.) comprises 15 species, seven of which endemic to Madagascar, six widespread in eastern Africa from Somalia southwards to Natal, one species, T. africanum Lour., recorded from both Madagascar and eastern Africa and one species, T. panduriforme Juss., from Madagascar and Mauritius (Elffers et al. 1964; Hadj Moustapha Haddade 1965; Harvey et al. 1995). The genus includes small trees, shrubs and a single herbaceous species ( $T$. roseomaculatum Y.B.Harv. \& Vollesen), with simple or 1 - 3-foliolate leaves and in some cases with tuberous roots, occurring in dry lowland and mountain forests, riverine formations, deciduous woodlands, xerophilous bushlands and thickets, secondary scrubs, dunes and grasslands, from sea level up to $1600 \mathrm{~m}$ a.s.l. With regard to the generic name, the spelling Thylacium was adopted in Flora Zambesiaca (Wild 1960), Thylachium in Flora of Tropical East Africa (Elffers et al. 1964) and in Flore de Madagascar et des Comores (Hadj Moustapha Haddade 1965). Later the original spelling Thilachium was conserved (McVaugh 1968), and adopted in Flora of Somalia by Thulin (1993), and by Harvey et al. (1995) in describing a new species from Kenya. Historically Thilachium was included by Pax \& Hoffman (1936) with the genera Maerua Forssk. and Courbonia Brongn. — in the tribe Maerueae Baill. belonging to the subfamily Capparoideae Burnett. Later DeWolf (1962) treated Courbonia as a synonym of Maerua and underlined that Thilachium "is a somewhat anomalous genus" showing affinities also with the genus Ritchiea R.Br. More recently Kers (2003) did not retain the subdivision of Capparoideae in tribes proposed by Pax \& Hoffman (1936), stating that Thilachium is related, in addition to Maerua and Ritchiea, to other Old World woody genera, i.e. Boscia Lam., Bachmannia Pax and Cadaba Forssk. The same author (Kers 2003) distinguished Thilachium from the allied genera mainly by the sepals connate, rupturing transversally at the midline, the conical calyptra tardily falling off and the absence of petals. With regard to the phylogeny of Capparaceae, Hall et al. (2002), based on chloroplast sequence data, identified within subfamily Capparoideae a mostly African Old World clade including Thilachium, Maerua, Ritchiea, Boscia and Cadaba.

Since the treatment of family Capparaceae provided by Hadj Moustapha Haddade (1965) no recent studies are available for Madagascar, which constitutes a centre of speciation of the genus Thilachium. During investigations on herbarium collections, material from the Lam \& Meeuse expedition to Madagascar in 1938, originally identified as Capparis sp., turned out to belong to the genus Thilachium. Based on various differential features from the species known from Madagascar and eastern Africa, this specimen is referred to as a new species, distinguished by its leaf morphology and by the inflorescence and flower characters. The new species is here described and illustrated, its affinities are discussed and a key to the species of the genus is provided.

\footnotetext{
Accepted for publication 20 March 2021. Published online 30 September 2021

1 Department of Agricultural, Food and Forest Sciences, University of Palermo, Palermo, Italy. e-mail: silvio.fici@unipa.it
} 


\section{Materials and Methods}

Herbarium investigations were carried out on historical and recent collections of Capparaceae from the Old World kept at the Nationaal Herbarium Nederland, Leiden University branch (L). To my knowledge the new species here described has been collected only once, in December 1938, by Lam \& Meeuse in eastern Madagascar (Lam $\mathcal{E}$ Meeuse 5840).

The description and illustration are based on herbarium material. The species concept follows the one adopted by Elffers et al. (1964) and Hadj Moustapha Haddade (1965). The terminology of the vegetative and reproductive structures, as well as the main diagnostic characters within the genus, are based on the same treatments. The herbarium acronyms follow Thiers (continuously updated), while authors and plant names are based on IPNI (2020). The examination of type specimens of other species of Thilachium was carried out through electronic images available at JSTOR Global Plants (n.d.). The online collections available at $\mathrm{P}, \mathrm{K}$ and $\mathrm{MO}$ and the Catalogue of the Vascular Plants of Madagascar (n.d.) were also consulted. The conservation status was provisionally assessed according to IUCN Red List Categories and Criteria (IUCN 2012).

\section{Taxonomic Treatment}

Thilachium madagascariense Fici sp. nov. Type: Madagascar, Soanierana-Antasibe [Andasibe], $350 \mathrm{~m}, 10$ Dec. 1938, Lam E̋ Meeuse 5840 (holotype L 1851991!; isotype P 05457232 digital image!).

http://www.ipni.org/urn:lsid:ipni.org:names:77218374-1

Small tree c. $5 \mathrm{~m}$ tall. Branches greyish or reddish, beset with lenticels; twigs glabrous. Leaves 1-foliolate; blade chartaceous, elliptic or narrowly obovate, $(7.5-) 10-15.3 \times(2-) 3.3-5$ $\mathrm{cm}$; base attenuate; apex acuminate with tip $0.7-1.5 \mathrm{~cm}$ long; surfaces glabrous; veins c. $5-8$ on each side of the midrib; petiole $(1.1-) 2-4 \mathrm{~cm}$ long, glabrous, striate, articulate at the top; stipules $0.5 \mathrm{~mm}$ long or caducous. Flowers white, $2-3$ conferted at the top of lateral twigs; pedicels $12-18 \mathrm{~mm}$ long, glabrous; bracts $0.2-0.5 \mathrm{~mm}$ long; flower buds c. $9-10 \times 7-9 \mathrm{~mm}$, with calyx at maturity rupturing transversally, the calyptra remaining attached at one side in the available material; receptacle c. $2-3 \mathrm{~mm}$ in diam.; petals 0; androgynophore $1-1.5 \mathrm{~mm}$ long, glabrous; stamens c. 57 - 70, filaments (20-) 23-30 mm long, anthers $1.5-2 \mathrm{~mm}$ long with thecae divergent at the base when mature; gynophore (20 -) 23- $26 \mathrm{~mm}$ long, glabrous; ovary oblong, $3-4 \times 1-1.5 \mathrm{~mm}$ long, glabrous, striate, stigma sessile, flattened. Fruit unknown. Fig. 1.

RECOGNITION. Related to Thilachium laurifolium Baker in the articulate petiole of similar length and pauciflorous inflorescence, but differs in the longer, acuminate leaf blade, (7.5
-) 10 - $15.3 \mathrm{~cm}$ long vs subemarginate, $2.5-7.5 \mathrm{~cm}$ long, flowers $2-3$ conferted at the top of lateral twigs vs $4-6$ in corymbs, shorter pedicels, $1.2-1.8 \mathrm{~cm}$ long vs $(3-) 3.5-$ $5 \mathrm{~cm}$ long, higher number of stamens, c. $57-70$ vs c. $30-46$, and shorter gynophore, $(2-) 2.3-2.6 \mathrm{~cm}$ long vs c. $5-7$ (8) $\mathrm{cm}$ long (Table 1). With regard to other 1-foliolate species from Madagascar, T. madagascariense differs from T. monophyllum Hadj-Moust. in the longer petiole, (1.1 -) 2 $-4 \mathrm{~cm}$ long vs $0.8-1.2 \mathrm{~cm}$ long, longer leaf blade, (7.5 -) 10 $-15.3 \mathrm{~cm}$ long vs $5-8 \mathrm{~cm}$ long, shorter pedicels, $1.2-1.8 \mathrm{~cm}$ long vs $2.3-2.5 \mathrm{~cm}$ long and higher number of stamens, $\mathrm{c}$. $57-70$ vs 25 - 30, and from T. pouponii Aubrév. \& Pellegr. in the shorter petiole, $(1.1-) 2-4 \mathrm{~cm}$ long vs c. $10 \mathrm{~cm}$ long, larger leaf blade, $(7.5-) 10-15.3 \times(2-) 3.3-5 \mathrm{~cm}$ vs $4-$ $5 \times 0.5-1 \mathrm{~cm}$, shorter pedicels, $1.2-1.8 \mathrm{~cm}$ long vs $3-$ $4 \mathrm{~cm}$ long, lower number of stamens, c. 57 - 70 vs c. $90-$ 100 and shorter gynophore, (2-) $2.3-2.6 \mathrm{~cm}$ long vs $6-$ $7 \mathrm{~cm}$ long (Table 1).

DISTRIBUTION AND HABITAT. The new species is only known from the type, which was collected in forest habitats of eastern Madagascar with Sphenomeris decomposita C.Chr., Cyathea boivinii var. hildebrandtii (Kuhn) Janssen \& Rakotondr., Tambourissa capuronii Cavaco, Exacum subacaule Humbert, Burasaia sp., Neodypsis lastelliana Baill., Dypsis nodifera Mart., Ravenala madagascariensis Sonn., at an elevation of $350 \mathrm{~m}$.

SPECIMENS EXAMINED. MADAGASCAR. SoanieranaAntasibe [Andasibe], $350 \mathrm{~m}, 10$ Dec. 1938, Lam E Meeuse 5840 (holotype L; isotype P).

CONSERVATION STATUS. Lacking information to assess its risks, Thilachium madagascariense is categorised as Data Deficient (DD).

PHENOLOGY. Flowering in December (based on the available material).

VERNACULAR NAME. "Tafolona" (malagasy).

NOTES. Thilachium madagascariense is mainly distinguished by its leaf and inflorescence characters, as well as by the length of pedicels, number of stamens and length of gynophore. As mentioned above, among the species of the genus with 1-foliolate leaves $T$. madagascariense shows some affinities with T. laurifolium, endemic to central and eastern Madagascar (Hadj Moustapha Haddade 1965; Catalogue of the Vascular Plants of Madagascar n.d.) (Table 1). The new species is also related to T. thomasii Gilg, recorded from eastern Kenya and southern Somalia, which is distinguished by the shorter petioles $(0.4-) 0.5-0.9$ $(-1.4) \mathrm{cm}$ long, shorter, coriaceous or slightly fleshy leaf blade $3-9.3 \mathrm{~cm}$ long, inflorescence a $1-10$ flowered loose corymbose raceme and lower number of stamens (c. $18-25$ ) with longer anthers c. $3 \mathrm{~mm}$ long (Elffers et al. 1964; Thulin 1993) (Table 1). Other species with 1-foliolate leaves from Madagascar and eastern Africa, e.g. T. monophyllum, T. pouponii, T. paradoxum Gilg, T. roseomaculatum Y.B.Harv. \& Vollesen, are readily recognisable by several vegetative and reproductive characters (Table 1). A key to all the 


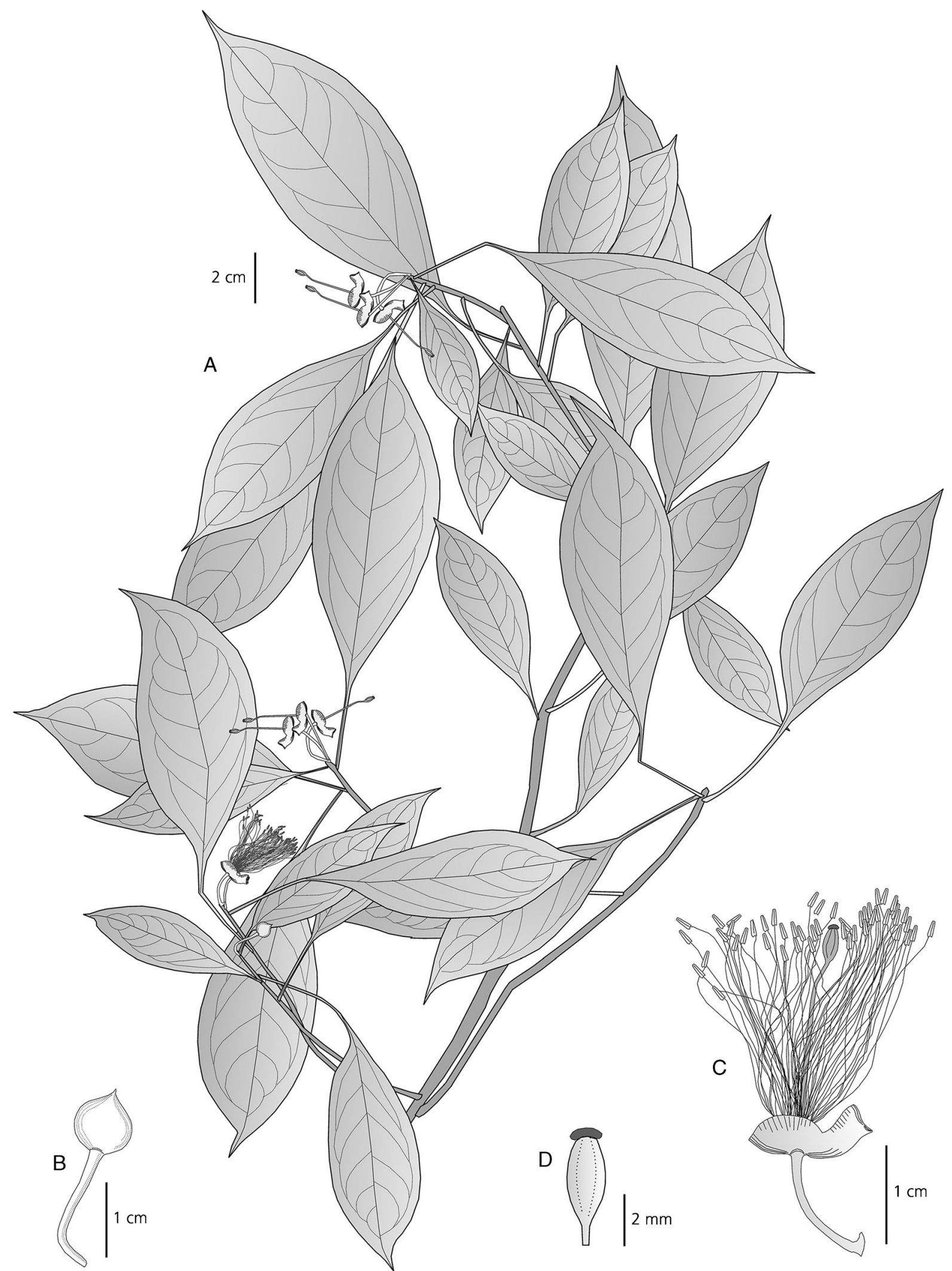

Fig. 1. Thilachium madagascariense. A flowering branch; B flower bud; C flower; D ovary. All from Lam \& Meeuse 5840 (holotype L). DRAWN BY SILVIO FICI. 


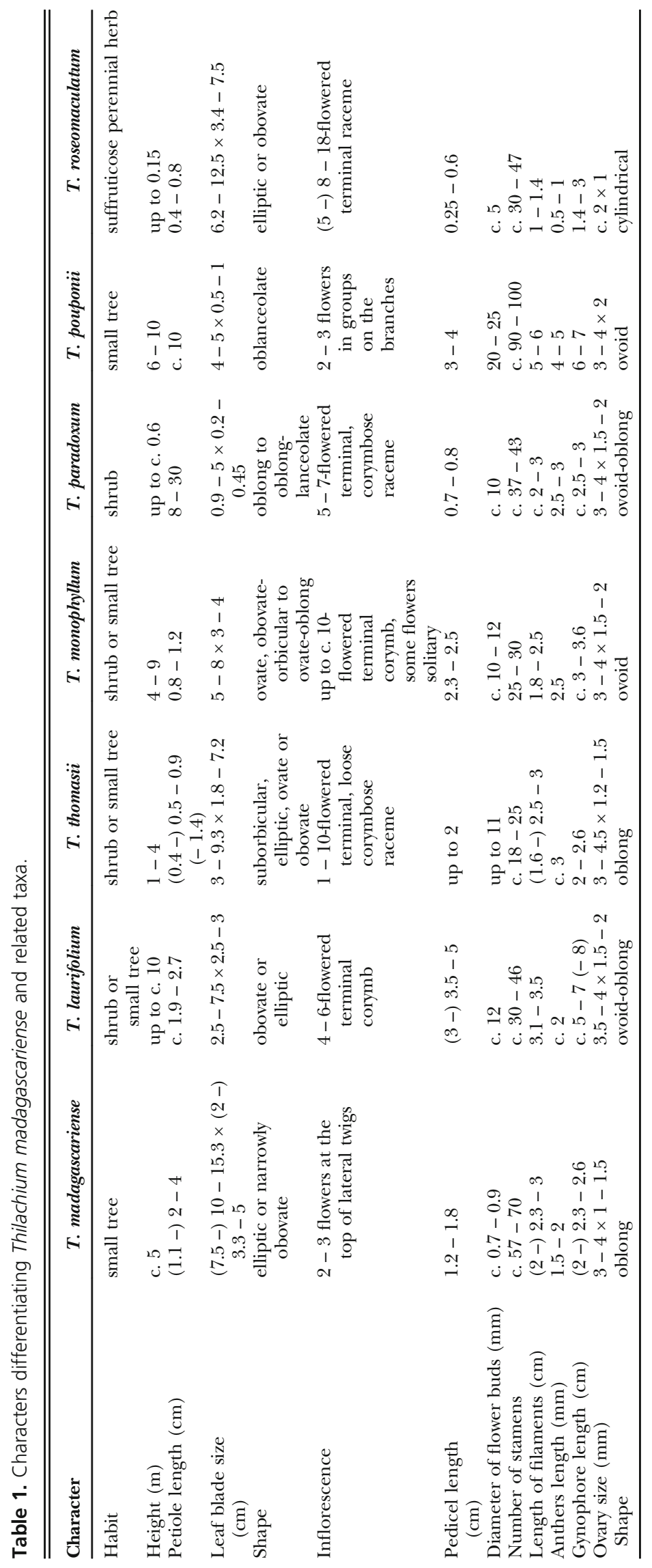


species of Thilachium known from eastern Africa and Madagascar is provided below.

The description of this new species confirms Madagascar as a centre of speciation of the genus Thilachium, which includes here three other species with 1-foliolate leaves, i.e. T. laurifolium, T. monophyllum and T. pouponii, and six species with 3-foliolate leaves, in some cases intermixed with 1foliolate leaves, i.e. T. africanum Lour., T. angustifolium Bojer, T. humbertii Hadj-Moust., T. panduriforme Juss., T. seyrigii Hadj-Moust. and T. sumangui Bojer. All these taxa, with the exception of $T$. africanum and $T$. panduriforme, are endemic to the island, where they are widespread along the coast and inland in xerophilous bushlands and woodlands, deciduous forests, dunes and riverine formations on limestone, gneiss, laterite, sandstone, alluvial and sandy-clay soils (Hadj Moustapha Haddade 1965). Within the Malagasy species, the pulp of the fruit is reported as sweet and edible in $T$. pouponii and $T$. laurifolium, while traditional medicinal uses are recorded for $T$. seyrigii.
Lam \& Meeuse carried out their expedition to Madagascar from November to December 1938, landing at Tamatave on 4 November after visiting Réunion and Mauritius; in addition to wishing to address the lack of plant materials from Madagascar in the European Herbaria outside Paris, they were interested in the many ancient forms present in the island and in its floristic affinities with Malesia (Jacobs 1984). This was mainly a collecting trip, during which many areas of the island, up to $1550 \mathrm{~m}$ elevation, were explored. Lam \& Meeuse collected 1030 numbers of herbarium specimens from the island (Jacobs 1984), currently kept at the Nationaal Herbarium Nederland (L and WAG) and including several types. Among these are the types of Dichaetanthera lancifolia H.Perrier (Melastomataceae) and Decarydendron lamii Cavaco (Monimiaceae), collected in the same locality as Thilachium madagascariense. The discovery of this new species confirms that historical collections are still a relevant source of data for taxonomic studies in less explored areas.

\section{Key to the species of Thilachium}

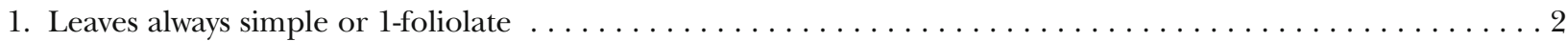

- Leaves 3-foliolate, rarely with simple leaves intermixed or on fertile branches $\ldots \ldots \ldots \ldots \ldots$

2. Suffruticose perennial herb; leaves with conspicuous pink spots $\ldots \ldots \ldots \ldots \ldots$. . . . . roseomaculatum

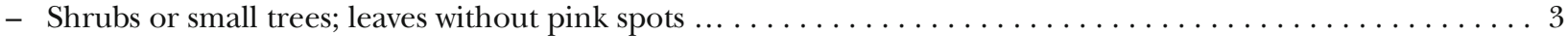

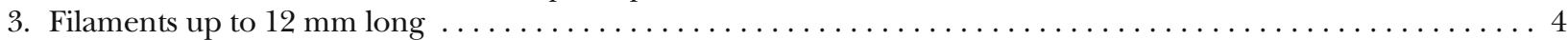

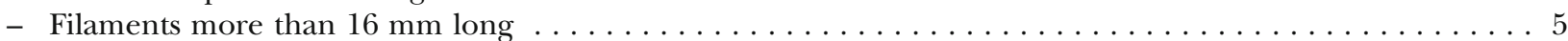

4. Leaf blade $15-24 \times 8-11 \mathrm{~cm}$; filaments $11-12 \mathrm{~mm}$ long . . . . . . . . . . . . . . T. macrophyllum

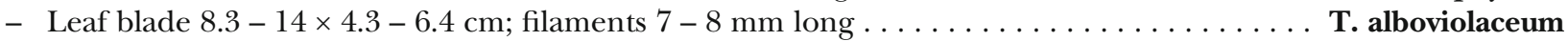

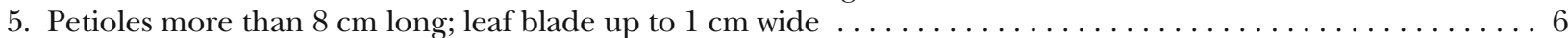

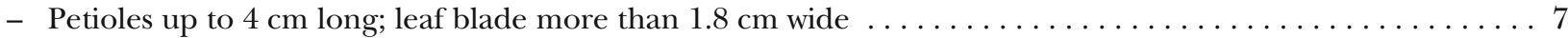

6. Petioles $8-30 \mathrm{~cm}$ long; leaf blade small, $9-50 \times 2-4.5 \mathrm{~mm}$, or frequently absent $\ldots \ldots \ldots$. . . paradoxum

- Petioles c. $10 \mathrm{~cm}$ long; leaf blade $40-50 \times 5-10 \mathrm{~mm} \ldots \ldots \ldots \ldots \ldots \ldots \ldots \ldots \ldots$. . . . . . . . . pouponii

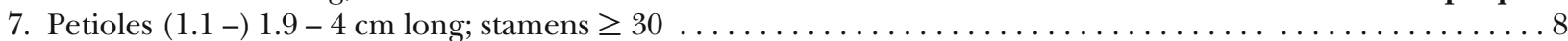

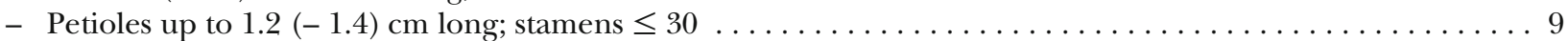

8. Leaf blade subemarginate $2.5-7.5 \mathrm{~cm}$ long; $4-6$ flowers in terminal corymbs; pedicels $(3-) 3.5-5 \mathrm{~cm}$ long; stamens c. $30-46$; gynophore c. $5-7(-8) \mathrm{cm} \operatorname{long} \ldots \ldots \ldots \ldots \ldots \ldots \ldots \ldots \ldots \ldots \ldots$. . . . . . laurifolium

- Leaf blade acuminate (7.5 -) $10-15.3 \mathrm{~cm}$ long; 2 - 3 flowers at the top of lateral twigs; pedicels $1.2-1.8 \mathrm{~cm}$

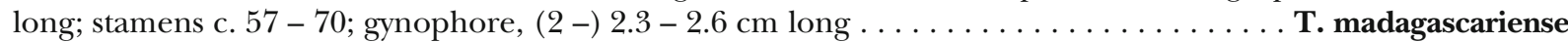

9. Pedicels $2.3-2.5 \mathrm{~cm}$; fruit $1.5-2 \mathrm{~cm} \operatorname{long} \ldots \ldots \ldots \ldots \ldots \ldots \ldots \ldots \ldots \ldots \ldots \ldots$. $\ldots \ldots \ldots$. monophyllum

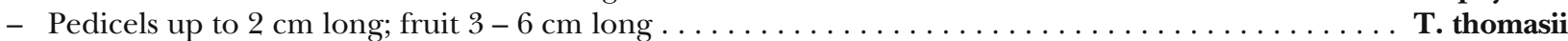

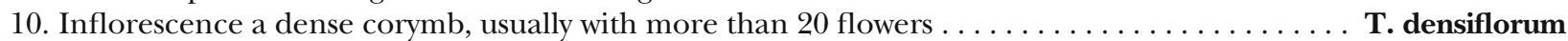

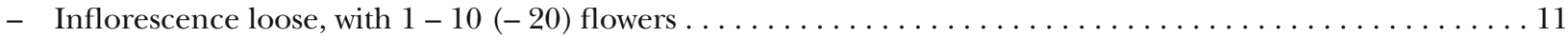

11. Leaflets linear or oblong, $0.2-1.2 \mathrm{~cm}$ wide $\ldots \ldots \ldots \ldots \ldots \ldots \ldots \ldots \ldots \ldots \ldots \ldots \ldots \ldots$. angustifolium

- Leaflets elliptic, lanceolate, oblanceolate, ovate, obovate or panduriform, $(0.6-) 1-5.3 \mathrm{~cm}$ wide . . . . 12

12. Leaflets heteromorphic, lanceolate and panduriform; simple leaves present on fertile branches ...... T. panduriforme

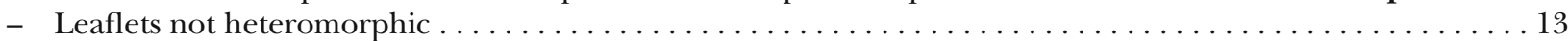

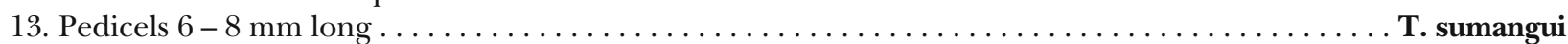

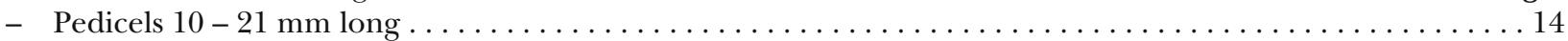

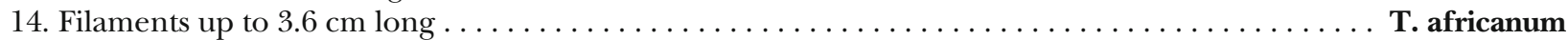

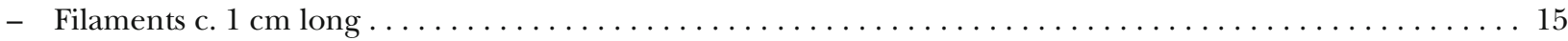


15. Pedicels c. $1-1.3 \mathrm{~cm}$ long; stamens c. 15 ; fruit $4-5 \mathrm{~cm} \operatorname{long} \ldots \ldots \ldots \ldots \ldots \ldots \ldots$. . . . . . . . . . . . . . .

- Pedicels $1.5-2 \mathrm{~cm}$ long; stamens $30-40$; fruit $0.7-0.8 \mathrm{~cm}$ long $\ldots \ldots \ldots \ldots \ldots \ldots$. $\ldots \ldots$ seyrigii

\section{Acknowledgements}

I am grateful to the staff of $\mathrm{L}$ for their collaboration.

\section{Funding}

Open access funding provided by Università degli Studi di Palermo within the CRUI-CARE Agreement.

Open Access This article is licensed under a Creative Commons Attribution 4.0 International License, which permits use, sharing, adaptation, distribution and reproduction in any medium or format, as long as you give appropriate credit to the original author(s) and the source, provide a link to the Creative Commons licence, and indicate if changes were made. The images or other third party material in this article are included in the article's Creative Commons licence, unless indicated otherwise in a credit line to the material. If material is not included in the article's Creative Commons licence and your intended use is not permitted by statutory regulation or exceeds the permitted use, you will need to obtain permission directly from the copyright holder. To view a copy of this licence, visit http://creativecommons.org/ licenses/by/4.0/.

\section{References}

Catalogue of the Vascular Plants of Madagascar (n.d.). Missouri Botanical Garden, St. Louis, \& Antananarivo, Madagascar. Available from: http:// legacy.tropicos.org/Name/40013340?projectid=17. Accessed 16 March 2021.

DeWolf, G. P. (1962). Notes on African Capparidaceae: III. Kew Bull. 16: $75-83$.

Elffers, J., Graham, R. A. \& DeWolf, G. P. (1964). Capparidaceae. In: C. E. Hubbard \& E. MilneRedhead (eds), Flora of Tropical East Africa. Whitefriars Press Ltd., London and Tonbridge.

Hadj Moustapha Addade, S. E. M. (1965). Capparidacées. In: H. Humbert (ed.), Flore de Madagascar et des Comores. 83. Muséum national d'Histoire Naturelle, Laboratoire de Phanérogamie, Paris.
Hall, J. C., Sytsma, K. J. \& Iltis, H. H. (2002). Phylogeny of Capparaceae and Brassicaceae based on chloroplast sequence data. Amer. J. Bot. 89: 1826 - 1842.

Harvey, Y. B., Luke, W. R. Q. \& Vollesen, K. B. (1995). Thilachium roseomaculatum (Capparaceae): new species from Kenya. Kew Bull. 50: 155 - 160.

IPNI (2020). International Plant Names Index. Royal Botanic Gardens, Kew, Harvard University Herbaria \& Libraries and Australian National Botanic Gardens. Available from: http://www.ipni.org. Accessed 12 Jan. 2021.

IUCN (2012). IUCN Red List categories and criteria: Version 3.1. 2nd ed. IUCN, Gland and Cambridge.

Jacobs, M. (1984). Herman Johannes Lam (1892 - 1977), the life and work of a Dutch Botanist. Rodopi, Amsterdam.

JSTOR Global Plants (n.d.). Ithaka. Available from: https://plants.jstor.org/. Accessed 16 March 2021.

Kers, L. E. (2003). Capparaceae. In: K. Kubitzki \& C. Bayer (eds), The Families and Genera of Vascular Plants. Vol. 5. Flowering Plants. Dicotyledons. Malvales, Capparales and Non-betalain Caryophyllales: 36 - 56. Springer, Berlin, Heidelberg.

McVaugh, R. (1968). Report of the Committee for Spermatophyta: Conservation of Generic Names, IX. Taxon 17: $325-329$.

Pax, F. \& Hoffman, K. (1936). Capparidaceae. In: A. Engler \& K. Prantl (eds), Die Natürlichen Pflanzenfamilien, ed. 2, 17b: 146 - 233. W. Engelmann, Leipzig.

Thiers, B. (continuously updated). Index Herbariorum: A Global Directory of Public Herbaria and Associated Staff. New York Botanical Garden's Virtual Herbarium. Available from: http://sweetgum.nybg.org/ science/ih/. Accessed 13 Jan. 2021.

Thulin, M. (1993). Thilachium. In: M. Thulin (ed.), Flora of Somalia 1: 53. Royal Botanic Gardens, Kew.

Wild, H. (1960). Capparidaceae. In: A. W. Exell \& H. Wild (eds), Flora Zambesiaca 1: 194 - 245. Crown Agents for Oversea Governments and Administrations, London.

\section{Publisher's Note}

Springer Nature remains neutral with regard to jurisdictional claims in published maps and institutional affiliations. 